\title{
PENGARUH PENGGUNAAN MEDIA PEMBELAJARAN ONLINE (Whatsapp dan Zoom) TERHADAP PRESTASI BELAJAR SISWA PADA MASA PANDEMI COVID-19
}

\author{
Naning Eko Noviana ${ }^{1}$, M Riadhos Solichin ${ }^{2}$ \\ IKIP WIdya Darma Surabaya \\ ${ }^{1}$ naning.ekonoviana@gmail.com, ${ }^{2}$ riadhos1986@gmail.com
}

\section{DOI}

https://doi.org/10.26740/jupe.v9n2.p6064

\author{
Article history \\ Received \\ 1 March 2021 \\ Revised \\ 5 March 2021 \\ Accepted \\ 6 March 2021
}

\section{How to cite}

Noviana, N. E., \& Solichin, M. R. (2021). Pengaruh penggunaan media pembelajaran online (whatsapp dan zoom) terhadap prestasi belajar siswa pada masa pandemi covid-19. Jurnal Pendidikan Ekonomi (JUPE), 9(2), 60-64.

https://doi.org/10.26740/jupe.v9n2.p6064

Kata Kunci: media pembelajaran online, prestasi belajar

Keywords: online learning media, learning achievement

\section{Corresponding author}

Naning Eko Noviana, naning.ekonoviana@gmail.com

\begin{abstract}
Abstrak
Tujuan dari penelitian ini adalah untuk mengetahui pengaruh penggunaan media pembelajaran online terhadap prestasi belajar siswa pada masa pandemi Covid19. Sampel dalam penelitian ini menggunakan sampel random sampling dari kelas XI Akuntansi 1 dan 2 SMK Kemala Bhayangkari 1 Waru Sidoarjo Pendekatan penelitian yang digunakan dalam penelitian ini adalah penelitian kuantitatif. Analisis regresi dalam penelitian ini menggunakan bantuan sofwere SPSS 21 for windows. Hasil penelitian menunjukkan adanya pengaruh positif penggunaan media pembelajaran online terhadap prestasi belajar siswa pada masa pandemic Covid-19.
\end{abstract}

\begin{abstract}
The objective of this study to determine the effect of the use of online learning media on student's learning achievement in the covid-19 pandemic. The sample in this study used a random sample from class XI Accounting 1 dan 2 SMK Kemala Bhayangkari 1 Waru Sidoarjo The research approach used in this research is quantitative research. Regression analysis in this study using SPSS 21.0 for windows software. The results showed that the use of online learning media had a positive effect on student achievement during the Covid-19 pandemic.
\end{abstract}




\section{PENDAHULUAN}

Pendidikan formal merupakan unsur penting dalam mendidik dan melatih seorang anak. Pendidikan saat ini lebih banyak mengharuskan siswa untuk belajar menggunakan media yang memanfaatkan sumber teknologi. Hal ini bertujuan dalam memudahkan baik guru maupun siswa belajar. Penggunaan teknologi yang digunakan pun juga harus memenuhi standar pendidikan pada era industri 4.0 saat ini. Pengelolaan yang tepat mampu membuat kemajuan dibidang pendidikan karena siswa dapat menyumbangkan ide mereka melalui pembelajaran yang selaras dengan kemajuan teknologi.

Seperti yang diungkapkan oleh (Djamarah, 2000) diantaranya adalah guru sebagai pengelola proses pembelajaran; siswa selaku pemeran utama dalam proses pembelajaran; tujuan pembelajaran yang menjadi sasaran dari pencapaian proses pembelajaran; bahan ajar sebagai bahan yang digunakan untuk membantu guru dalam proses pembelajaran dikelas; cepat dan mudahnya mendapatkan sumber bahan pembelajaran; lingkungan sekitar pada saat proses pembelajaran.

Pada poin ke 4 (empat) ulasan diatas menyatakan bahwa bahan ajar sebagai bahan yang digunakan untuk membantu guru dalam proses pembelajaran dikelas. Berkaitan dengan ulasan diatas bahwa bahan ajar memerlukan media pembelajaran. Media pembelajaran merupakan suatu alat yang digunakan guru untuk menyampaikan isi dan tujuan pembelajaran. Teknologi sendiri merupakan media yang efektif dan efisien dalam memberikan materi kepada siswa.

Menurut seorang ahli media pembelajaran (Dabbagh, 2012) beberapa indikator pembelajaran online, sebagai berikut diantaranya spirit belajar, literacy terhadap teknologi, kemampuan berkomunikasi interpersonal, berkolaborasi, dan keterampilan belajar mandiri.

Sedangkan menurut (Hardianto, 2012) terdapat 8 kompetensi yang harus dimiliki oleh guru dalam pembelajaran online, yaitu sebagai berikut: menguasai dan update terhadap perkembangan internet; lebih menguasai ilmu pengetahuan pokok dan pendamping; kreatif dan inovatif dalam menyajikan materi; mampu memotivasi siswa; kemampuan dalam desain pembelajaran online; kemampuan mengelola sistem pembelajaran online; ketepatan dalam pemilihan bahan ajar online learning; dan kemampuan dalam mengontrol proses pembelajaran.

Pemberian pembelajaran secara online pada masa pandemi atau wabah Covid-19 sangatlah berperan penting. Wabah ini telah terjadi kurang lebih sudah satu tahun berjalan yang dimulai bulan Maret 2020 sampai saat ini. Wabah Covid-19 sendiri sangat berbahaya bagi anak-anak jika keadaan mereka memiliki imun sangat rendah, maka dari itu sekolah mulai memberlakukan pembelajaran melalui daring (dalam jaringan).

Pembelajaran secara online sebetulnya masih harus dilakukan perbaikan baik dalam melayani siswa dan dalam proses KBM. Sehingga hal ini juga berdampak pada prestasi belajar siswa. Prestasi belajar merupakan suatu perubahan yang dicapai seseorang setelah mengikuti proses belajar (slameto, 2003). Sedangkan prestasi belajar mempunyai beberapa fungsi sebagai berikut (Arifin, 2011) antara lain sebagai indikator kualitas dan kuantitas pengetahuan yang telah dikuasai anak didik, sebagai lambang pemuas hasrat ingin tahu, sebagai bahan informasi dalam inovasi pendidikan, dan dapat dijadikan sebagai indikator terhadap daya serap anak didik.

Menurut penelitian yang dilakukan oleh (Darnita, Marhaeni, \& Candiasa, 2014) yang berjudul menyatakan bahwa terdapat pengaruh penggunaan bahan ajar online terhadap prestasi belajar siswa dengan kovariabel aktivitas belajar siswa kelas VIII SMP Dwijendra Gianyar pada semester 2 tahun pelajaran 2013/2014.

Kemudian menurut penelitian yang dilakukan oleh (Aurora \& Effendi, 2019) yang berjudul menyatakan bahwa terdapat pengaruh positif dan signifikan antara penggunaan media pembelajaran elearning dengan motivasi belajar mahasiswa. Penelitian lain juga disebutkan oleh (Rahmatia, Monawati, \& Darnius, 2017) yang berjudul menyatakan bahwa terdapat pengaruh media e-learning terhadap hasil belajar.

Dampak dari pandemik ini sangat dirasakan oleh kebanyakan guru dan murid manakala guru dan murid belum bisa menerapkan secara penuh bagaimana pembelajran yang akan dilakukan secara total menggunakan tenologi secara daring (dalam jaringan). Hal ini juga dirasakan pula oleh guru-guru yang sudah berusia lanjut karena mereka harus belajar secara otodidak bagaimana mengajarakan materi secara online.

Setelah dilakukan wawancara awal dengan salah satu siswa menyatakan bahwa pembelajaran daring menggunakan sistem online sudah dilakukan oleh sebagian besar siswa di SMK Kemala Bhayangakri 1 Waru. Sehingga peneliti tertarik untuk meneliti lebih lanjut mengenai "Pengaruh Penggunaan Media Pembelajaran Online (Whatsapp dan Zoom) Terhadap Prestasi Belajar Siswa Pada Masa Pandemi COVID-19”.

\section{METODE}

Penelitian dilakukan pada siswa jurusan Akuntansi kelas XI Akuntnasi 1 dan 2 SMK Kemala 
Bhayangkari 1 Waru Sidoarjo. Adapun sebab pengambilan lokasi dilakukan kepada siswa Jurusan Akuntansi yang sudah dan siap memiliki media atau alat yang digunakan dalam pembelajaran online. Populasi dalam penelitian ini adalah siswa jurusan Akuntansi kelas XI Akuntansi 1 dan 2 SMK Kemala Bhayangkari 1 Waru Sidoarjo sebanyak 52 anak. Sampel dalam penelitian ini menggunakan random sampling. Random sampling di ambil secara acak dengan jumlah sampel yang sama dari dua kelas yang berbeda yaitu 15 anak dari XI AK 1 dan 15 anak dari XI AK 2 sehingga total sampel menjadi 30 siswa. Sampel yang dipilih dalam penelitian ini memiliki kriteria sudah dan siap memiliki media atau alat yang digunakan dalam pembelajaran online.

Tabel 1: Distribusi siswa kelas XI AK SMK Kemala Bhayangkari 1 Waru

\begin{tabular}{|c|c|c|c|}
\hline No. & Kelas & Populasi & Sampel \\
\hline 1. & XI AK 1 & 27 & 15 \\
\hline \multirow[t]{2}{*}{2.} & XI AK 2 & 25 & 15 \\
\hline & Total & 52 & 30 \\
\hline
\end{tabular}

Intrumen dalam penelitian ini berbetuk kuesioner yang diberikan kepada responden yaitu siswa Jurusan Akuntansi Kelas XI Akuntansi 1 dan 2 SMK Kemala Bhayangkari kepada sebanyak 30 anak. Indikator yang dijabarkan dari pembelajaran menggunakan media online ini sebanyak 20 butir pernyataan. Setelah menjabarkan indikator-indikator baik variabel bebas maupun terikat maka secara keseluruhan akan diuji coba menggunakan uji validitas dan reliabilitas.

Tabel 2. Indikator

\begin{tabular}{|c|c|c|}
\hline No & Variabel & Indikator \\
\hline \multirow[t]{5}{*}{1.} & \multirow{5}{*}{$\begin{array}{c}\text { Pembelajaran online } \\
\text { (Dabbagh, 2007) }\end{array}$} & Spirit belajar \\
\hline & & Literacy \\
\hline & & $\begin{array}{l}\text { Komunikasi } \\
\text { interpersonal }\end{array}$ \\
\hline & & Berkolaborasi \\
\hline & & Belajar mandiri \\
\hline \multirow[t]{4}{*}{2.} & \multirow{4}{*}{$\begin{array}{l}\text { Prestasi Belajar } \\
\text { (Kompri, 2017) }\end{array}$} & Lingkungan, \\
\hline & & Faktor guru \\
\hline & & Faktor siswa \\
\hline & & $\begin{array}{c}\text { Faktor } \\
\text { kurikulum }\end{array}$ \\
\hline
\end{tabular}

Metodologi yang digunakan dalam penelitian ini adalah metode deskriptif kuantitatif. Teknik analisis data yang digunakan untuk menjawab rumusan masalah yang sesuai dengan penelitian ini yaitu teknik analisis regresi sederhana. Analisis regresi sederhana digunakan untuk mengukur pengaruh antara satu variabel bebas dengan variabel terikat. Menurut (Siregar, 2014) penerapan metode regresi sederhana merupakan pengaruh variabel bebas yang mempengaruhi satu variabel tak bebas. Analisis regresi dalam penelitian ini menggunakan bantuan sofwere SPSS 21 for windows. Uji penelitian menggunakan regresi sederhana terdapat dua yaitu uji prasyarat dan uji hipotesis. Uji prasyarat meliputi uji normalitas dan uji heterokesdastisitas. Sedangkan uji hipotesis yaitu uji $\mathrm{t}$ dan hasil regresi sederhana.

\section{HASIL}

Hasil penelitian yang sudah dilakukan oleh peneliti ini membahas tentang penelitian kuantitatif yang diperoleh hasil dari penyebaran kuesioner kepada responden. Responden yang digunakan dalam penelitian adalah siswi SMK Kemala Bhayangkari 1 Waru. Pengambilan sampel data sebanyak 30 anak dari total populasi 52 anak dengan 2 rombongan belajar. Sampel diambil dari kelas XI Akuntansi.

\section{Uji Prasyarat}

Hasil uji normalitas data dilakukan dalam peneitian ini guna mengetahui apakah ditribusi data berjalan normal atau tidak. Dengan indeks jika nilai signifikan (Asymp.sig) > 0,05 maka data berdistribusi normal dan sebaliknya. Dalam penelitian ini memakai uji normalitas metode Kolmogorov-Smirnov dengan menggunakan sofwere SPSS 21.0 for windows. berikut adalah hasil normalitas data:

Tabel 3: One-Sample Kolmogorov-Smirnov Test Unstandardized Residual

\begin{tabular}{|c|c|c|}
\hline $\mathrm{N}$ & & 36 \\
\hline \multirow[b]{2}{*}{ Normal Parameters ${ }^{\mathrm{a}, \mathrm{b}}$} & Mean & $0 \mathrm{E}-7$ \\
\hline & $\begin{array}{c}\text { Std. } \\
\text { Deviation }\end{array}$ & 1,80011040 \\
\hline \multirow{3}{*}{$\begin{array}{l}\text { Most Extreme } \\
\text { Differences }\end{array}$} & Absolute &, 166 \\
\hline & Positive & 166 \\
\hline & Negative &,- 108 \\
\hline \multicolumn{2}{|c|}{ Kolmogorov-Smirnov Z } & ,997 \\
\hline \multicolumn{2}{|c|}{ Asymp. Sig. (2-tailed) } &, 274 \\
\hline \multicolumn{3}{|c|}{ a. Test distribution is Normal. } \\
\hline \multicolumn{3}{|c|}{ b. Calculated from data. } \\
\hline
\end{tabular}

Dari data diatas menunjukkan bahwa nilai Kolmogorov-Smirnov $\mathrm{Z}=0,99$ dengan nilai sig. $>0,05$ yaitu 0,274. Maka dapat dinyatakan data berdistribusi normal. Sehingga dapat dilanjutkan analisis selanjutya. Analisis selanjutnya yaitu mengenai hasil heterokesdastisitas. Uji heterokesdastisitas dilakukan untuk menilai apakah data memiliki varians yang tidak sama. Penilaian data dilakukan jika data menyebar secara acak dalam suatu diagram titik maka dapat 
dikatan analisis regresi tepat dilakukan. Berikut adalah hasil uji heterokesdastisitas:

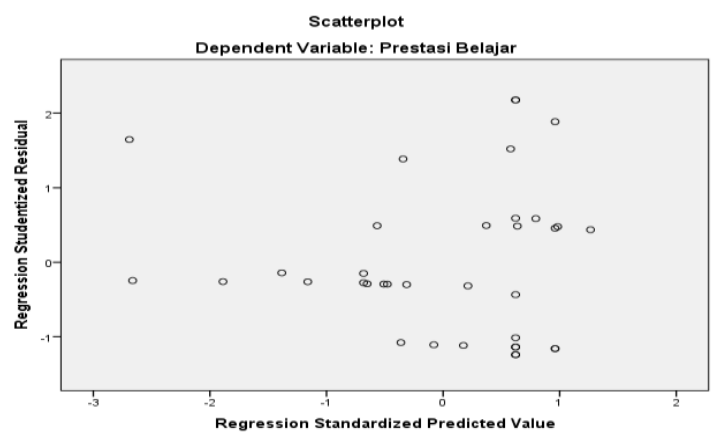

Gambar 1: uji heterokesdastisitas

Garmbar diagram diatas menggambarkan bahwa persebaran titik di sumbu X dan sumbu Y terlihat secara acak. Sehingga dapat disimpulkan bahwa varian tidak mengandung heterokesdastisitas atau bersifat homogen.

\section{Uji Hipotesis}

Uji t digunakan dalam penelitian ini untuk mengetahui pengaruh secara parsial antara variabel bebas terhadap variabel terikat. Penilaian uji t diperoleh melalui perhitungan probabilitas $<0,05$ maka dapat dikatakan bahwa variabel bebas berpengaruh terhadap secara parsial. Berikut ini adalah hasil dari uji t:

Tabel 4: uji t

\begin{tabular}{llccc}
\hline & \multicolumn{4}{c}{ Coefficients $^{\mathrm{a}}$} \\
\hline Model & $\begin{array}{c}\text { Unstandardi } \\
\text { zed } \\
\text { Coefficients }\end{array}$ & $\mathrm{t}$ & Sig. \\
\cline { 3 - 5 } & $\mathrm{B}$ & & \\
\hline \multirow{3}{*}{1} & $\begin{array}{c}\text { Media } \\
\text { Pembelajar } \\
\text { an Online }\end{array}$ &, 427 & 0,790 &, 000 \\
\cline { 2 - 4 } & & 16,789 &, 000 \\
\hline
\end{tabular}

a. Dependent Variable: Prestasi Belajar

Berdasarkan hasil uji t terhadap variabel X2 dapat diketahui bahwa nilai Standardized Coefficients yang mana ditunjukkan oleh variabel media pembelajaran online sebesar 0,427 dengan nilai signifikan $0,000<0,05$. Sehingga $H_{o}$ ditolak, maka ada pengaruh langsung antara media pembelajaran online terhadap prestasi belajar secara signifikan. Hasil uji t juga dapat diketahui bahwa variabel $X$ yaitu pmedia pembelajaran online secara parsial berpengaruh signifikan terhadap variabel $\mathrm{Y}$ yaitu prestasi belajar. Nilai koefisien yang dihasilakn sebesar ,427 memiliki nilai positif yang berarti bahwa variabel $\mathrm{X}$ meningkatkan mengakibatkan variabel $\mathrm{Y}$ meningkat, begitu pula sebaliknya jika $\mathrm{X}$ menurun maka $\mathrm{Y}$ juga akan menurun.

\section{PEMBAHASAN}

Penelitian ini bertujuan untuk menguji pengaruh antara variabel bebas yaitu media pembelajarn online (X1) terhadap variabel terikat yaitu prestasi belajar (Y). Berdasarkan hasil penelitian yang telah dilakukan oleh peneliti bahwa ada pengaruh langsung dan positif antara media pembelajaran online dengan prestasi belajar. Jika media pembelajarn online ditingkatkan maka prestasi belajar siswa kelas XI Akuntansi SMK Kemala Bhanyangkari 1 Waru juga meningkat dan sebaliknya. Dari hasil kajian hipotesis pertama terbukti bahwa ada pengaruh signifikan antara varibel bebas media pembelajaran online terhadap variabel terikat yaitu prestasi belajar.

Hal ini sesuai dengan pernyataan Darnita Tahun 2014 yang berjudul menyatakan bahwa terdapat pengaruh penggunaan bahan ajar online terhadap prestasi belajar siswa.

Berdasakan hasil angket yang diberikan kepada responden sebanyak 30 anak pada siswa kelas XI Akuntansi SMK Kemala Bhanyangkari 1 Waru mengenai media pembelajaran online diantaranya meliputi media pembelajaran online (Whatsapp dan Zoom) dapat menumbuhkan keingitahuan siswa mengenai mata pelajaran yang diajarkan oleh guru; media pembelajaran online (Whatsapp dan Zoomyang dilakukan oleh guru mempermudah siswa untuk mengikuti pelajaran; media pembelajaran online (Whatsapp dan Zoom) membuat siswa berawawasan luas dalam membaca bahasa sistem perangkat lunak, media pembelajaran online (Whatsapp dan Zoom) memberikan siswa kemampuan dalam membaca dan menulis dalam bahasa pemrograman sistem, media pembelajaran online (Whatsapp dan Zoom) mengajarkan siswa dalam berkomunikasi jarak jauh dengan teman, media pembelajaran online (Whatsapp dan Zoom) dapat menampilkan gambar dengan lawan jenis saat pembelajaran berlangsung seperti Video Call, media pembelajaran online (Whatsapp dan Zoom) memberi siswa kemudahan dalam berkomunikasi dengan teman dan guru, siswa dapat mengerjakan tugas yang diberikan oleh guru melalui media whatsapp, siswa dapat mengerjakan tugas yang bersifat kelompok dengan teman saya menggunakan media Whatsapp, siswa dapat menyajikan materi menggunakan media Zoom dengan mempresentasikan hasil kerja kelompok dengan video call, siswa dapat belajar secara mandiri dengan bantuan media pembelajaran online, dan siswa menjadi tidak tergantung pada teman ketika siswa belajar dengan media pembelajaran online.

Seperti yang dijelaskan oleh Cisco (dalam Yazdi:2012) mengenai fungsi pembelajaran e-learning sebagai berikut: (1) e-learning merupakan penyampaian informasi, komunikasi, pendidikan, pelatihan secara off- 
line atau on-line; e-learning menyediakan seperangkat alat yang dapat memperkaya nilai beljar secara konvensional (model pembelajaran konvensional, kajian terhadap buku teks, CD-ROM, dan pelatihan berbasis computer) sehingga dapat menjawab tantangan perkembangan globalisasi; e-learning tidak berarti menggantikan model belajar konvensionaldidalam kelas, tetapi memperkuat model belajar tersebut melalui pengayaan contents dan pengembangan teknologi pendidikan; dan kapasitas siswa amat bervariasi tergantung pada bentuk isi dan cara penyampaiannya.

Hal ini berkaitan dengan pernyataan seorang ahli media pembelajaran Dabbagh, N (2007) beberapa indikator pembelajaran online, sebagai berikut diantaranya spirit belajar, literacy terhadap teknologi, kemampuan berkomunikasi interpersonal, berkolaborasi, dan keterampilan belajar mandiri.

\section{SIMPULAN}

Kesimpulan dari hasil penelitian mengenai pengaruh media pembelajaran online terhadap prestasi belajar di SMK Kemala Bhayangkari 1 Waru untuk kelas XI Akuntansi 1 dan 2 bahwa terdapat pengaruh langsung dan positif antara media pembelajaran online dengan prestasi belajar. Media pembeljaran online memiliki pengaruh positif dapat diartikan bahwa jika media pembelajaran online meningkat yang meliputi indikator spirit belajar, literacy, komunikasi interpersonal, berkolaborasi, dan belajar mandiri maka prestasi belajar juga akan meningkat.

\section{DAFTAR PUSTAKA}

Arifin. (2011). Metode Penelitian Kualitatif, Kuantitatif, dan $R \& D$. Bandung: Alfabeta.

Aurora, A., \& Effendi, H. (2019). Pengaruh Penggunaan Media Pembelajaran E-learning terhadap Motivasi Belajar Mahasiswa di Universitas Negeri Padang. Jurnal Teknik Elektro Vokasional, 5(2), 11-16. Retrieved from http://ejournal.unp.ac.id/index.php/jtev/index

Dabbagh, N. (2012). Learner Characteristics and Online Learning. SpringerReference, 7, 217-226. https://doi.org/10.1007/springerreference_302098

Darnita, I. K., Marhaeni, A. A. I. N., \& Candiasa, M. (2014). Pengaruh penggunaan Bahan Ajar Online Terhadap Prestasi Belajar TIKOM dengan Kovariabel Aktivitas Belajar Siswa Kelas VIII SMP Dwijendra Gianyar. Jurnal Pendidikan Dasar Ganesha, 4(1), 123459. Retrieved from https://www.neliti.com/publications/123459/

Djamarah, S. B. (2000). psikologi pendidikan. Jakarta: PT Asdi.

Hardianto, D. (2012). Karateristik Pendidik Dan Peserta
Didik Dalam Pembelajaran Online. Majalah Ilmiah Pembelajaran, 8(2), 1-10.

Kompri. (2017). Faktor-Faktor yang Mempengaruhi Prestasi Belajar. Yogyakarta: Media Akademi.

Rahmatia, M., Monawati, \& Darnius, S. (2017). Pengaruh Media E-Learning Terhadap Hasil Belajar Matematika Siswa Kelas Iv Sdn 20 Banda Aceh. Jurnal Ilmiah Pendidikan Guru Sekolah Dasar FKIP Unsyiah, 2(1), 212-227.

Siregar, S. (2014). Metode Penelitian. Jakarta: PT Fajar. Slameto. (2003). Belajar dan Faktor-faktor yang mempengaruhi. Jakarta: Rineka Cipta. 